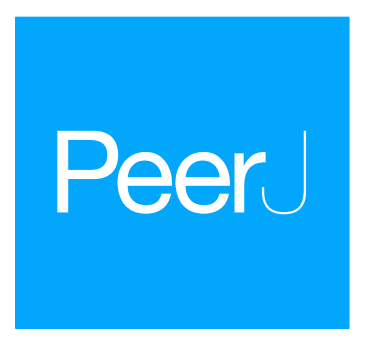

Submitted 4 March 2017

Accepted 14 May 2017

Published 13 June 2017

Corresponding author

Eduardo Morteo, emorteo@uv.mx,

eduardo.morteo@gmail.com

Academic editor

Patricia Gandini

Additional Information and Declarations can be found on page 16

DOI 10.7717/peerj.3415

Copyright

2017 Morteo et al.

Distributed under

Creative Commons CC-BY 4.0

OPEN ACCESS

\section{Phenotypic variation in dorsal fin morphology of coastal bottlenose dolphins (Tursiops truncatus) off Mexico}

\author{
Eduardo Morteo ${ }^{1}$, Axayácatl Rocha-Olivares ${ }^{2}$, Rodrigo Morteo $^{3}$ and \\ David W. Weller ${ }^{4}$ \\ ${ }^{1}$ Instituto de Ciencias Marinas y Pesquerías/Instituto de Investigaciones Biológicas, Universidad Veracruzana, \\ Boca del Río/Xalapa, Veracruz, Mexico \\ ${ }^{2}$ Centro de Investigación Científica y de Educación Superior de Ensenada, Ensenada, Baja California, Mexico \\ ${ }^{3}$ Facultad de Ciencias Administrativas y Sociales, Universidad Autónoma de Baja California, Ensenada, Baja \\ California, Mexico \\ ${ }^{4}$ Southwest Fisheries Science Center, Marine Mammal and Turtle Division, National Oceanic and Atmospheric \\ Administration, La Jolla, CA, United States of America
}

\section{ABSTRACT}

Geographic variation in external morphology is thought to reflect an interplay between genotype and the environment. Morphological variation has been well-described for a number of cetacean species, including the bottlenose dolphin (Tursiops truncatus). In this study we analyzed dorsal fin morphometric variation in coastal bottlenose dolphins to search for geographic patterns at different spatial scales. A total of 533 dorsal fin images from 19 available photo-identification catalogs across the three Mexican oceanic regions (Pacific Ocean $n=6$, Gulf of California $n=6$ and, Gulf of Mexico $n=7$ ) were used in the analysis. Eleven fin shape measurements were analyzed to evaluate fin polymorphism through multivariate tests. Principal Component Analysis on logtransformed standardized ratios explained $94 \%$ of the variance. Canonical Discriminant Function Analysis on factor scores showed separation among most study areas $(p<$ 0.05 ) with exception of the Gulf of Mexico where a strong morphometric cline was found. Possible explanations for the observed differences are related to environmental, biological and evolutionary processes. Shape distinction between dorsal fins from the Pacific and those from the Gulf of California were consistent with previously reported differences in skull morphometrics and genetics. Although the functional advantages of dorsal fin shape remains to be assessed, it is not unlikely that over a wide range of environments, fin shape may represent a trade-off among thermoregulatory capacity, hydrodynamic performance and the swimming/hunting behavior of the species.

Subjects Animal Behavior, Biogeography, Ecology, Marine Biology, Zoology

Keywords Adaptations, Stepping stone model, Population discrimination, Polymorphism

\section{INTRODUCTION}

Fin shape in aquatic organisms has been suggested to reflect unique anatomical and physiological adaptations to different environmental conditions (Aleyev, 1977; Pauly \& Palomares, 1989; Fish, 1998; Weller, 1998; Wright, 2000), and this is also widely accepted in cetaceans (Fish \& Hui, 1991; Berta \& Sumich, 1999; Fish \& Rohr, 1999; Reynolds, Wells \& Eide, 2000; Morteo, 2003). Morphological variation of the dorsal fin, to some extent, has 
been used for population and/or species identification (Lang \& Pryor, 1966; Aleyev, 1977; Fish, 1998; Weller, 1998; Morteo, Morteo \& Rocha-Olivares, 2005; Felix et al., 2017).

The dorsal fin of delphinids is important at two functional levels: thermoregulatory and hydrodynamic. Little empirical evidence exists, however, regarding the integrated performance of dorsal fins for most cetacean species (Lang, 1966; Weller, 1998; Fish \& Rohr, 1999; Meagher et al., 2002; Westgate et al., 2007; Barbieri et al., 2010; Pavlov \& Rashad, 2012; Van der Hoop et al., 2014). Estimating integrated performance is challenging since plasticity may be in part regulated by the energetic cost of different swimming behaviors related to locating, chasing, handling, and ingesting prey, thus maneuvering abilities may be important in feeding success, and the dorsal fin may play an important role for swimming stabilization (Weller, 1998; Fish \& Rohr, 1999). Also, the dorsal fin is the only appendage that is constantly exposed to ambient air, and thus is subject to different thermoregulatory conditions from the rest of the body (Meagher et al., 2002; Westgate et al., 2007; Barbieri et al., 2010).

Bottlenose dolphins (Tursiops truncatus) have a worldwide distribution, occupying a variety of ecological conditions, and show substantial intraspecific phenotypic variation (Walker, 1981; Vidal, 1993; Gao, Zhou \& Wang, 1995; Goodwin et al., 1996; Hoelzel, Potter \& Best, 1998; Turner \& Worthy, 2003; Weller, 1998). Polyphenisms in traits whose functions arose as adaptations to new life conditions (e.g., aquatic for terrestrial ancestors) may be directly linked to the environment, and morphometric variations should be studied as a function of ecological differences (Stearns, 1989; Gotthard \& Nylin, 1995). Here we analyze phenotypic variation of bottlenose dolphin dorsal fins in relation to respective habitats, ecology and behavior over different spatial scales. We evaluated the degree of fin polymorphisms of 19 putative populations from Mexico, contrasting them by location and region, in the context of relevant biological, ecological and geological features. The goal of the study was to determine if observed morphometric variations follow the stepping stone model, where the degree of differentiation among neighboring populations is correlated with the migration distance travelled by individuals (Wright, 1943; Kimura, 1953).

\section{METHODS}

\section{Study area}

Sampling locations were selected considering the following: (1) Geographic coverage should include most of the species distribution within Mexican coastal waters, (2) Locations should represent most of the existing conditions of habitat variability for the species in Mexico, (3) Distances among adjacent locations should allow for individual exchange considering the dispersal capabilities of the species, and (4) Photo-identification catalogs of coastal bottlenose dolphin populations must be available. Detailed descriptions on the ecology of the study areas and the biology of dolphin populations in those areas are provided elsewhere (see Espinosa, 1986; Ballance, 1987; Salinas \& Bourillón, 1988; Acevedo, 1989; Ballance, Leatherwood \& Reeves (1990); Ballance, 1992; Delgado, 1996; Delgado, 2002; Caldwell, 1992; Heckel, 1992; Schramm, 1993; Silber et al., 1994; Silber \& Fertl, 1995; López, 1996; López, 2002; Defran et al., 1999; Díaz, 2001; Orozco, 2001; Reza, 2001; Guzón, 2002; 


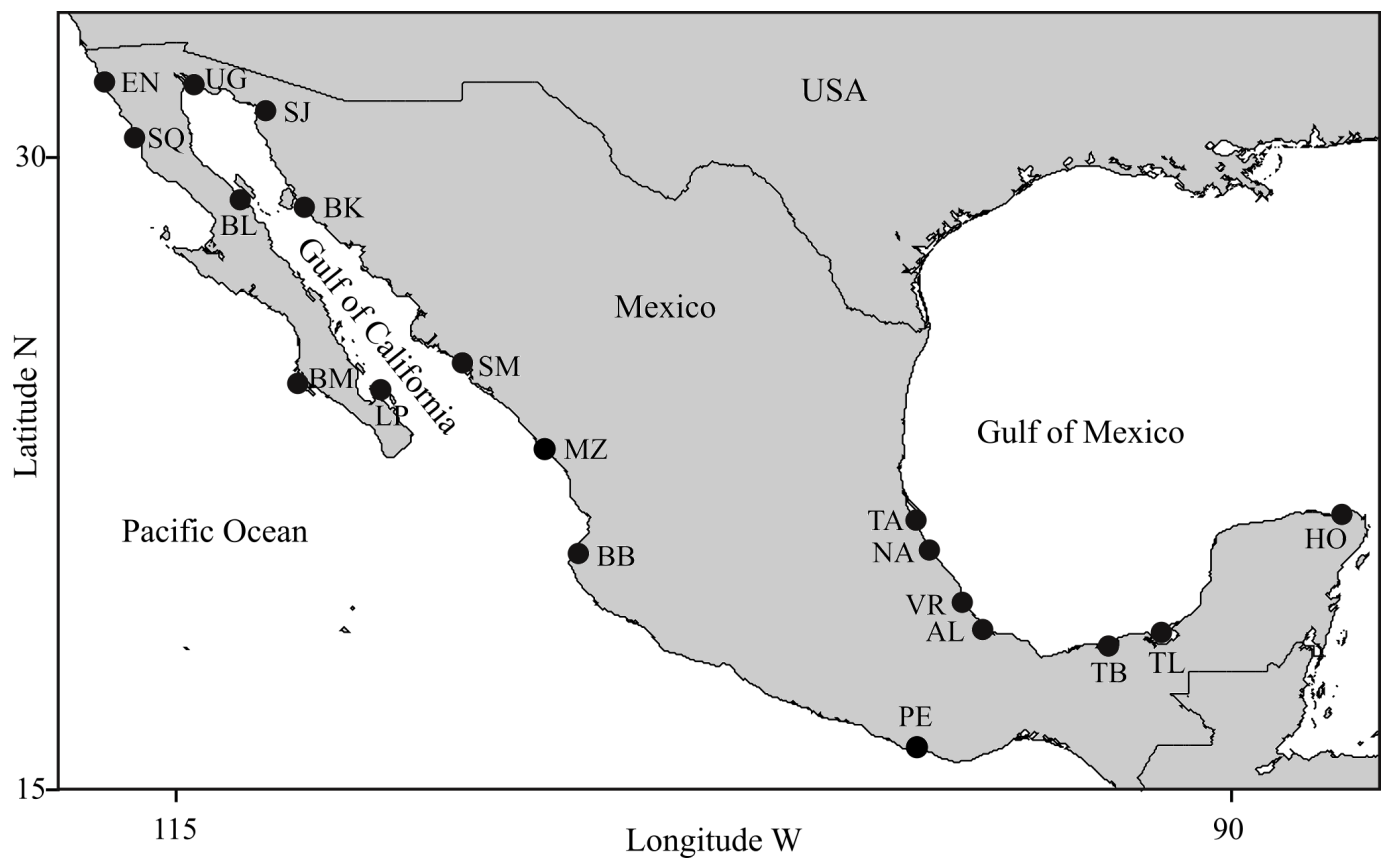

Figure 1 Study areas. (1) Pacific Ocean: EN, Ensenada, Baja California; SQ, San Quintin, Baja California; BM, Bahia Magdalena, Baja California; MZ, Mazatlán, Sinaloa; BB, Bahia Banderas, Jalisco; PE, Puerto Escondido, Oaxaca; (2) Gulf of California: UG, Upper Gulf of California, Sonora; SJ, Bahia San Jorge, Sonora; BL, Bahia de los Angeles, Baja California; BK, Bahia Kino, Sonora; SM, Bahia Santa Maria, Sinaloa; LP, La Paz, Baja California Sur; (3) Gulf of Mexico: TA, Tamiahua, Veracruz; NA, Nautla, Veracruz; VR, Veracruz Reef System, Veracruz; AL, Alvarado, Veracruz; TB, Tabasco, Tabasco; TL, Terminos Lagoon, Campeche; HO, Holbox, Quintana Roo.

Morteo, 2002; Rodríguez, Lugo \& Foubert, 2003; Ladrón de Guevara \& Heckel, 2004; Morteo et al., 2004; Ramírez, Morteo \& Portilla-Ochoa, 2005; Mellink-Bijtel \& Orozco-Meyer, 2006; Pérez-Cortes, 2006; Rodríguez-Vázquez, 2008; Morteo et al., 2012; Morteo, Rocha-Olivares \& Abarca-Arenas, 2014; Morteo et al., 2015; Morteo, Rocha-Olivares \& Abarca-Arenas, 2017; Ruíz-Hernández, 2014; Zepeda-Borja, 2017, unpublished data). Study areas were grouped by region into (1) Pacific Ocean, (2) Gulf of California and (3) Gulf of Mexico (Fig. 1). For instance, (1) the Mexican Pacific (i.e., localities EN, SQ, BM, MZ, BB and PE in Fig. 1) features an open habitat with a narrow continental shelf as a result of active processes of plate tectonics, thus coastal bathimetry has a steeper slope (usually depths $>40 \mathrm{~m}$ are reached at $<2 \mathrm{~km}$ from the shore), where swells are typically high $(>1.5 \mathrm{~m})$; the average sea surface temperature (SST) turns warmer through a north-south gradient $\left(15-30^{\circ} \mathrm{C}\right)$ and productivity is mostly dominated by coastal upwellings via ocean circulation and local primary producers (i.e., kelp beds); also, except for the southern portion of the study area (i.e., locality PE in Fig. 1), rainfall and coastal vegetation have little influence on the ecology of these areas, even within the estruaries and lagoons. (2) Conversely, the Gulf of California is a semiclosed habitat where ocean currents are complex due to the intricate bathimetry and the tidal regime; it has an exceptionally high primary productivity driven mostly by seasonal upwellings, shallow thermoclines and a wind-mixed water column. The Gulf of California has been divided into three oceanographic and biogeographically 
different regions from north to south, such that: (a) northern coastal waters (i.e., UG and SJ in Fig. 1) are shallow $(<10 \mathrm{~m})$, usually warmer $\left(>20^{\circ} \mathrm{C}\right)$ with high salinity and strong tidal currents (up to $1 \mathrm{~m} \mathrm{~s}^{-1}$ ); in contrast b) the central coast (i.e., BL and BK in Fig. 1) is steeper due to the deep Canal de Ballenas and Tiburon Island passages $(>1000 \mathrm{~m})$, with colder SST $\left(<20^{\circ} \mathrm{C}\right)$ due to frequent upwellings, and features high swells $(>2 \mathrm{~m})$ formed by strong winds $\left(>5 \mathrm{~m} \mathrm{~s}^{-1}\right)$; and c) the southern area (i.e., LP and SM in Fig. 1) has shallow bays $(<20 \mathrm{~m})$ bordered by a deeper coastal waters $(>100 \mathrm{~m})$ situated at the entrance to the Gulf; wave height and SST are highly variable throughout the year (except in location SM) and so is primary productivity due to the influence of the several water masses coming in from the Pacific. Finally, the Gulf of Mexico (i.e., TA, NA, VR, AL, TB, TL and HO in Fig. 1) is a very shallow area (usually depths around $20 \mathrm{~m}$ are reached over $4 \mathrm{~km}$ from the shore) where tides are very low $(<1 \mathrm{~m})$ and most of the oceanic circulation is driven by the loop current that carries warm waters (mean SST $>26^{\circ} \mathrm{C}$ ) from the Caribbean into the Gulf. Although the region is classified as an open habitat, many dolphin populations inhabit shallow (depth $<10 \mathrm{~m}$ ) lagoons (i.e., TA, TB and TL) or semi-protected coastal waters surrounded by reefs (i.e., VR) or islands (i.e., HO), thus swells are also very low $(<1 \mathrm{~m})$. Coastal productivity is usually higher around continental water bodies due to nutrient runoffs, especially during the rainy season; thus the ecology of most of these areas is strongly influenced by temporal changes in wind and rain regimes.

\section{Photographic procedures}

Dorsal fin shapes were obtained from high quality images; since our methods involved only non-invasive data collection (i.e., pictures were taken onboard a boat that was 15-50 m away from the animals), an institutional review board was unnecessary. Also, original photographs from wild dolphins were obtained through a federal permit (SGPA/DGVS/518) from Secretaría del Medio Ambiente y Recursos Naturales (SEMARNAT). The remaining images came from photo-identification catalogs in other published and unpublished scientific research; thus it was assumed that all these were approved by their institutional review boards (if applicable) and were issued with the federal permits for their field work, such that these can be consulted in each case. Most of the pictures were obtained during the late 90's and the following decade, comprising at least 21 different years of information (see Table 1). The oldest photographic material was collected in the early 80's (e.g., Bahía Kino by Ballance, 1987) or 90’s (e.g., Tamiaha Lagoon by Heckel, 1992; Schramm, 1993), but some catalogs were updated over the following years (e.g., Ensenada by Espinosa, 1986; Guzón, 2002); however, the average duration of sampling effort for each of these studies was 2.6 years $($ s.d. $=2.1$ ) (see Table 1).

Image quality was crucial for the analysis, thus the best image from each individual was selected from the photo-identification databases according to the following criteria (modified from Weller, 1998): (1) Images only of mature dolphins; (2) Dorsal fins entirely visible, as complete as possible, and non-parallaxed; (3) Fins size at least one ninth of the entire picture; (4) Whenever possible, pictures from individuals sighted in different schools were selected in order to minimize chances of genetic relatedness (i.e., trait heredity). Images not fulfilling at least the first three criteria were excluded. Due to the variety of sources and 
Table 1 Summary of data sources and sample size. Abbreviations for study areas follow those in Fig. 1.

\begin{tabular}{|c|c|c|c|c|c|c|}
\hline Source(s) & Area & Duration (y) & $N_{\text {Cat }}$ & Sample (\%) & Format & Pods \\
\hline Espinosa (1986), Defran et al. (1999), Guzón (2002) & $\mathrm{EN}$ & 3 & 144 & $27(19 \%)$ & $\mathrm{S}, \mathrm{T}$ & 20 \\
\hline Caldwell (1992), Morteo (2002), Morteo et al. (2004) & SQ & 2 & 220 & $29(13 \%)$ & $\mathrm{S}, \mathrm{T}$ & 16 \\
\hline Pérez-Cortes (2006) & $\mathrm{BM}$ & 5 & 211 & $30(14 \%)$ & $\mathrm{S}$ & 27 \\
\hline Zepeda-Borja (2017, unpublished data) & $\mathrm{MZ}$ & 3 & 210 & $30(14 \%)$ & $\mathrm{D}$ & 26 \\
\hline Rodríguez, Lugo \& Foubert (2003), Rodríguez-Vázquez (2008) & $\mathrm{BB}$ & 6 & 60 & $28(46 \%)$ & $\mathrm{D}$ & 12 \\
\hline This work & $\mathrm{PE}$ & $<1$ & 24 & $21(87 \%)$ & $\mathrm{D}$ & 4 \\
\hline This work & UG & $<1$ & 28 & $23(82 \%)$ & $\mathrm{D}$ & 3 \\
\hline Orozco (2001), Mellink-Bijtel \& Orozco-Meyer (2006) & SJ & 1 & 217 & $24(11 \%)$ & $\mathrm{S}, \mathrm{T}$ & N.A. \\
\hline Ladrón de Guevara \& Heckel (2004) & $\mathrm{BL}$ & 1 & 26 & $19(73 \%)$ & $\mathrm{D}, \mathrm{S}, \mathrm{P}, \mathrm{T}$ & 4 \\
\hline Ballance (1987), Ballance (1990), Ballance (1992) & BK & 2 & 155 & $30(19 \%)$ & $\mathrm{S}, \mathrm{T}$ & 17 \\
\hline Reza (2001) & SM & 1 & 637 & $25(4 \%)$ & $\mathrm{S}$ & N.A. \\
\hline Díaz (2001) & LP & 1 & 66 & $29(44 \%)$ & $\mathrm{P}$ & N.A. \\
\hline Heckel (1992), Schramm (1993) & TA & 3 & 51 & $20(39 \%)$ & S & N.A. \\
\hline Ramírez, Morteo \& Portilla-Ochoa (2005) & NA & 1 & 148 & $30(20 \%)$ & S & 17 \\
\hline Ruíz-Hernández (2014), Morteo et al. (2015) & VR & 2 & 93 & $30(32 \%)$ & $\mathrm{D}$ & 30 \\
\hline $\begin{array}{l}\text { Morteo et al. (2012), Morteo, Rocha-Olivares \& Abarca-Arenas } \\
\text { (2014), Morteo, Rocha-Olivares \& Abarca-Arenas (2017) }\end{array}$ & $\mathrm{AL}$ & 8 & 282 & $30(11 \%)$ & S, D & 30 \\
\hline López (1996), López (2002) & $\mathrm{TB}$ & 2 & 750 & $35(4 \%)$ & $\mathrm{S}$ & 28 \\
\hline Delgado (2002) & $\mathrm{TL}$ & 5 & 1,987 & $37(2 \%)$ & $\mathrm{D}, \mathrm{T}$ & N.A. \\
\hline \multirow[t]{2}{*}{ Delgado (1996), Delgado (2002) } & $\mathrm{HO}$ & 3 & 344 & $36(10 \%)$ & $\mathrm{T}$ & N.A. \\
\hline & Total & $21^{\mathrm{a}}$ & 5,653 & $533\left(32.3 \%^{\mathrm{b}}\right)$ & - & 234 \\
\hline
\end{tabular}

Notes.

$N_{\text {Cat }}$, Number of individuals in the catalog. Image format is classified by reliability from digital pictures (D), digitized negatives or slides (S), scanned pictures (P) and scanned traces (T). N.A., not available.

${ }^{a}$ Total number of different years.

${ }^{\mathrm{b}}$ Weighted average.

formats, $32 \%$ of the material came from film-based images, and a similar proportion was from digital pictures, whereas $28 \%$ were fin contour traces in paper and $8 \%$ came from printed pictures (see Table 1).

Approximately 30 different individuals were randomly selected from each locality; these were later compared to avoid potential inter-study area matches (which did not occur). All individuals were assumed to belong to the coastal form of the species, as specified in the original catalogs.

\section{Digital measurements}

We developed a software routine (Fin Shape v1.3) in the computer language Borland Builder $\mathrm{C}++5.0$, to specifically measure angles and distances between landmarks of dorsal fins following Weller (1998) and Morteo, Morteo \& Rocha-Olivares (2005). Images were digitized at high resolution (3,000 dpi), as needed, and measured consistently by a single trained operator (E. Morteo). Following Weller (1998), the anterior insertion point of the dorsal fin on the body (B) was identified by an abrupt change in the contour of the dolphin's back; also, the tip of the dorsal fin (A) was identified as the landmark furthest from point B (Fig. 2). Once these two points were identified, a connecting straight line 


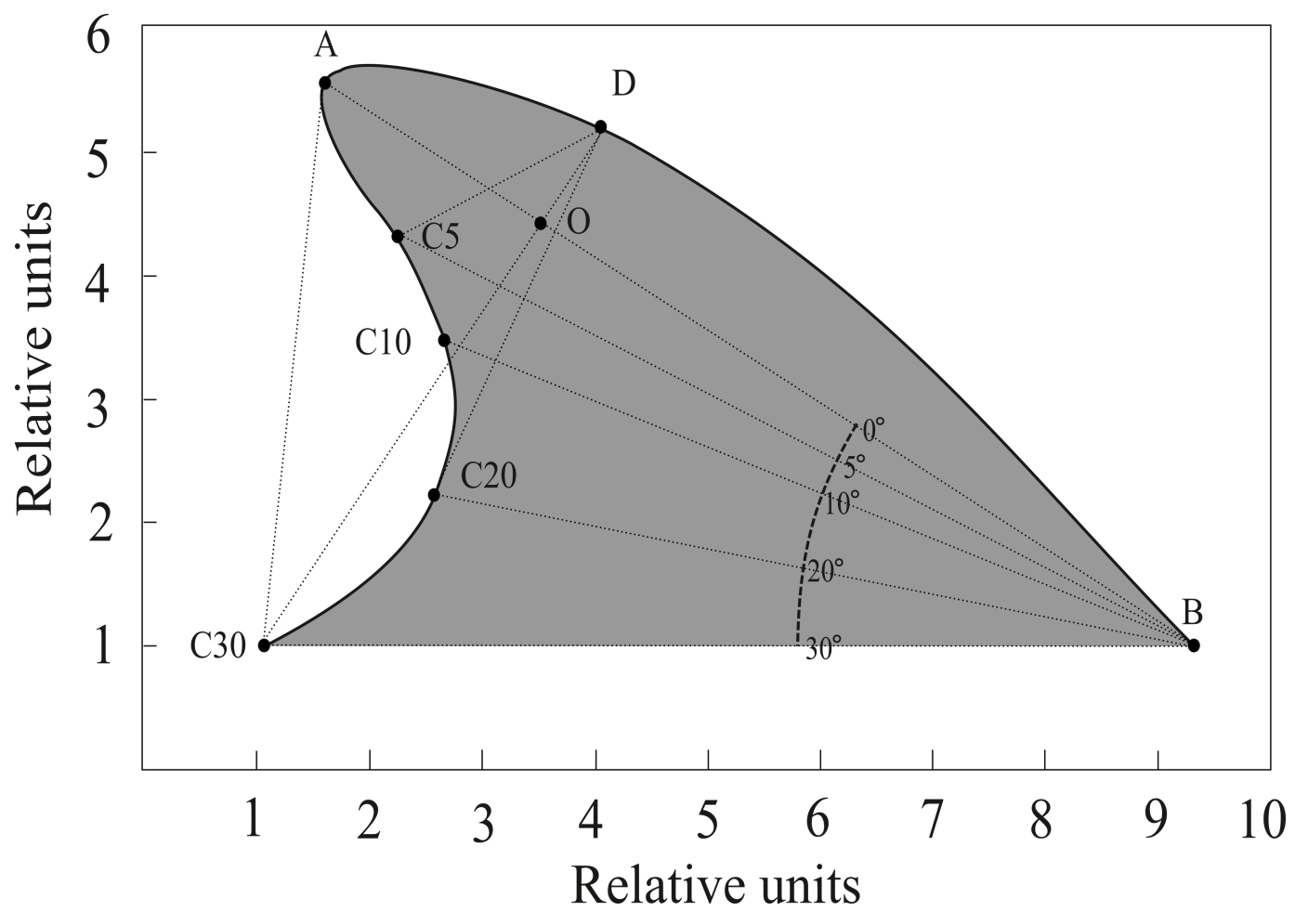

Figure 2 Reference points and measurements computed by FinShape software to acquire morphological landmarks. $\mathrm{A}=$ Tip; $\mathrm{B}=$ Base. Points $\mathrm{C}_{5}, \mathrm{C}_{10}, \mathrm{C}_{20}$ and $\mathrm{C}_{30}$ indicate angles (degrees) relative to line $\mathrm{AB}$. Point $\mathrm{D}$ is the intersection of a line departing from $\mathrm{C}_{30}$ with the fin's leading edge, this line is also perpendicular to line $\mathrm{AB}$. Point $\mathrm{O}$ is the intersection of lines $\mathrm{AB}$ and $\mathrm{C}_{30} \mathrm{D}$. Surface area (shaded) was calculated considering line $\mathrm{C}_{30} \mathrm{~B}$ as the limit.

was automatically drawn, and additional lines were projected departing from $\mathrm{B}$ at $30^{\circ}, 20^{\circ}$, $10^{\circ}$ and $5^{\circ}$ below segment $\mathrm{AB}$. The operator then identified where these lines intersected the edge of the fin, and their lengths were computed (in pixels).

Eleven measurements were obtained from each image along with the surface area (Fig. 2); these describe four qualitative shape parameters according to Weller (1998): (1) Base length: Distance from the leading edge to the trailing edge of the fin; (2) Depth: Distance from the fin tip to the anterior insertion on the body; (3) Rake: Amount that the tip of the fin extends beyond the base of the trailing edge; and (4) Foil: Curvature of the leading edge of the fin.

Since preliminary software trials by Morteo, Morteo \& Rocha-Olivares (2005) showed that repeated measures of the same image, and also of several different images from the same individual, yielded very little variations (i.e., $<0.1 \%$ ), it was assumed that the operator was able to correctly identify the features of the fin, and that image quality across all photographic formats was sufficient to prevent measuring bias. Measurements were used to calculate 11 indexes for each individual through the following standardized ratios (modified from Weller, 1998): $\mathrm{C}_{30} \mathrm{~B} / \mathrm{AB}, \mathrm{C}_{20} \mathrm{~B} / \mathrm{AB}, \mathrm{C}_{10} \mathrm{~B} / \mathrm{AB}, \mathrm{C}_{5} \mathrm{~B} / \mathrm{AB}, \mathrm{C}_{30} \mathrm{D} / \mathrm{AB}, \mathrm{C}_{20} \mathrm{D} / \mathrm{AB}$, $\mathrm{C}_{10} \mathrm{D} / \mathrm{AB}, \mathrm{C}_{5} \mathrm{D} / \mathrm{AB}, \mathrm{AO} / \mathrm{OB}, \mathrm{DO} / \mathrm{C}_{30} \mathrm{O}, \mathrm{AC}_{30}^{2} /$ area. 


\section{Morphological variation}

Average dorsal fin contours were constructed by locality based on median adimensional ratio values. In order to scale these contours, segment $A B$ was fixed to 10 relative units, thus all fin representations would have the same depth. The remaining segments were calculated through mathematical and trigonometrical equations that solved the related ratios using their correspondent median values (Morteo, Morteo \& Rocha-Olivares, 2005) (see Appendix S1); since the latter were not normally distributed, point Cartesian coordinates were computed from each median measurement, and data dispersion was represented as quartiles (upper $=75 \%$ and lower $=25 \%$ ) indicated by bars and ellipses around the calculated median points. This procedure follows a Procrustean approach (Peres-Neto \& Jackson, 2001), where distortion, scale and rotation are controlled to provide variation specificity for each reference point measure within the fin.

\section{Statistical analyses}

Phenotypic variability was assessed on log-transformed ratios (Zar, 1996) at three geographic scales: (1) within localities, (2) among localities (Isolation-Differentiation by distance), and (3) among oceanic regions.

Variation within localities was designed as a test for sample representativity through a rarefaction analysis. Local coefficients of variation (COV) were computed for each log-transformed ratio, which were later averaged to obtain a general index for the local variability of the fin (GIV). Variation among localities and regions was assessed through multivariate analyses of log-transformed ratios; since most of these ratios were highly correlated, a Principal Component Analysis (PCA) was performed. Individual scores from the PCA were used to perform a Discriminant Function Analysis (DFA) (tolerance $=0.01$ ) (Kachigan, 1991; Manly, 1994; Grimm \& Yarnold, 1995). Assumptions for multivariate tests were verified, and a non-stepwise Canonical Discriminant Analysis (CDA) was performed to determine separation among samples (tolerance $=0.01$ ). Also, $p$ values in multiple comparisons were later tested for significant differences by using the sequential Bonferroni correction (Rice, 1989). All data were analyzed using Statistica v6.0 (Stat Soft ${ }^{\mathrm{TM}}$ ).

Finally, Squared Mahalanobis Distances (SMD) from the DFA were used to construct a dendrogram (Single Linkage Cluster Analysis) and dissimilarities were expressed as percentages $\left(100^{*}\right.$ linkage SMD/Max SMD). SMDs were also used to perform an analysis of differentiation by distance, in which we correlated the matrix of phenotypic differentiation among localities (SMDs) with a matrix of geographic distances using a Mantel one-tailed test ( $\alpha=0.05$, Monte Carlo and 10,000 permutations) as implemented in the Excel (Microsoft Office XP ${ }^{\mathrm{TM}}$ ) add-in XLStat-Pro v7.0 (Addinsoft ${ }^{\mathrm{TM}}$ ). Due to the coastal nature of these dolphins, geographic distances among localities $(\mathrm{km})$ were calculated roughly following the coastline, thus these represent minimum separations among localities. Finally, we performed partial Mantel tests for each region in order to determine the contribution of each dataset to the general model. 


\section{RESULTS \\ Data overview}

A total of 5,653 dorsal fins were analyzed from the photo-id catalogs available at the 19 locations (Table 1). From all the images that fulfilled the quality criteria, a total of 533 individuals were randomly selected (representing 32.3\% of fins or individuals from all the catalogs). Except for Bahia de los Angeles, the Upper Gulf of California, and Puerto Escondido, the fins used in this study accounted for less than half the number of identified individuals; also, when sighting data were available, for any particular location most fins came from different pods, such that the average proportion of individuals from different pods at each study area was $61.2 \%$ (s.d. $=12.8 \%)$.

\section{General phenotypic variability}

The Cartesian position of each landmark in the standardized fins varied in decreasing order as follows $\mathrm{A} \rightarrow \mathrm{C}_{30} \rightarrow \mathrm{O} \rightarrow \mathrm{D} \rightarrow \mathrm{C}_{5}$; also, landmarks $C_{10}$ and $C_{20}$ were the least variable in all cases (represented by smaller ellipses) (Fig. 3). Fins within the Gulf of Mexico (Fig. 3C) showed the least variability overall; these were also the least falcate, contrasting with all the fin contours from the Pacific (Fig. 3A) and most from the Gulf of California (Fig. 3B). Average fin contours featured a larger base length for the fins from the Pacific and the Gulf of California (except Bahia de los Angeles). Wide rounded tips were also found for most Pacific dolphins (except for Puerto Escondido), and pointed tips prevailed in dolphins from the northern Gulf of California (Fig. 3B) (except San Joge, Santa María and La Paz) and the Gulf of Mexico (Fig. 3C). Also, fins from the Pacific and the Gulf of California had more foil, and most of their tips did not extend further from the posterior basal landmark (i.e., less rake) as in fins from the Gulf of Mexico (except for Bahia de los Angeles and Bahia Kino in the northern Gulf of California). Finally, fins from the Gulf of Mexico and the northern Gulf of California were slightly taller $\left(\mathrm{AC}_{30}\right)$, thus the surface area was also larger.

\section{Variability within localities}

As expected, variability within localities increased as more fins were included in rarefaction curves; however, these reached an asymptote at the 19th sample $(>95 \%$ of the local variability) in most localities; therefore the minimum sample size was inferred as 20 individuals (Fig. 4).

\section{Variability among localities}

The PCA performed on all eleven log-transformed ratios showed that $94.7 \%$ of the variance was explained by the first three factors, and the remaining seven factors accounted for less than $2 \%$ each, thus they were not useful in the following analyses (Table 2).

Scores from PCA were normally distributed $(p>0.2)$, and the DFA among the 19 locations was highly significant (Wilks' Lambda: 0.44442, $F_{(33,922)}=8.8617, p<0.00001$, $n=533)$. All three factors contributed significantly $(p<0.00001)$ to the model (Table 2$)$.

SMDs (Table 3) revealed widespread differentiation among locations. All sites were significantly different $(p<0.01)$ to at least 12 other study areas (i.e., Bahia Magdalena, 
A)

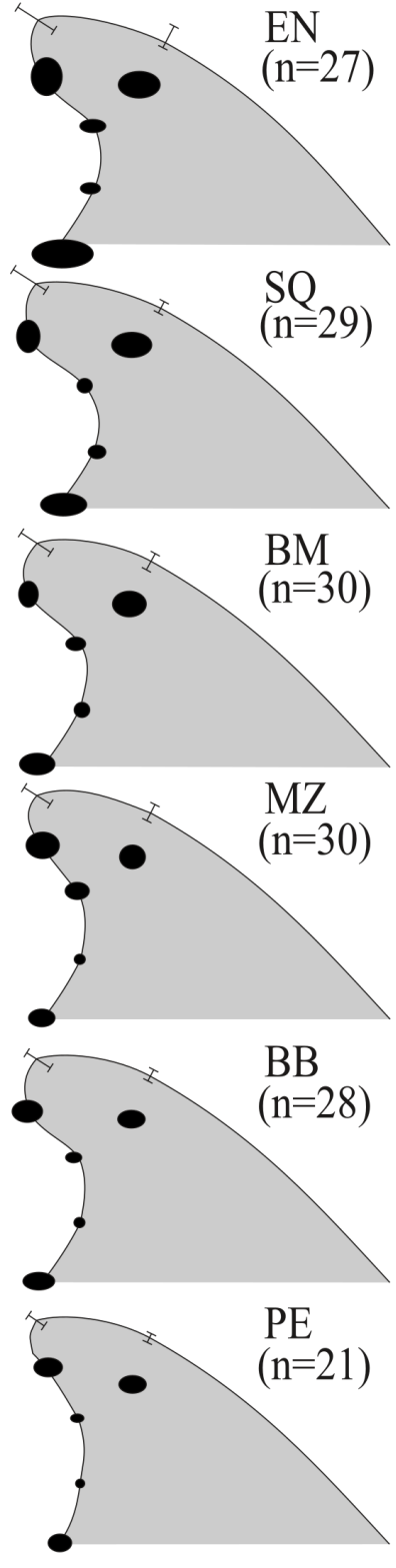

B)

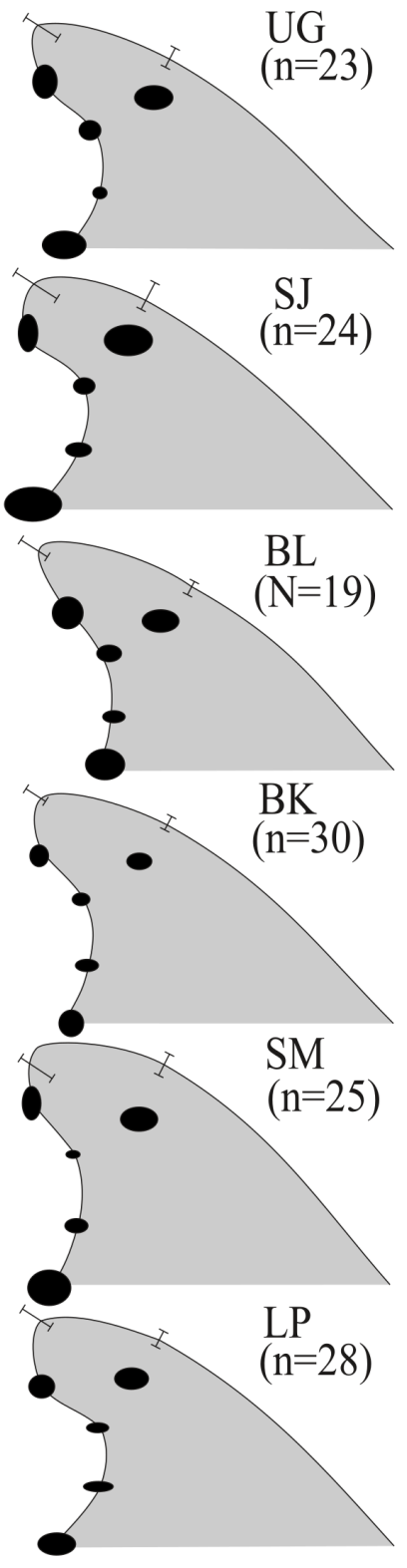

C)

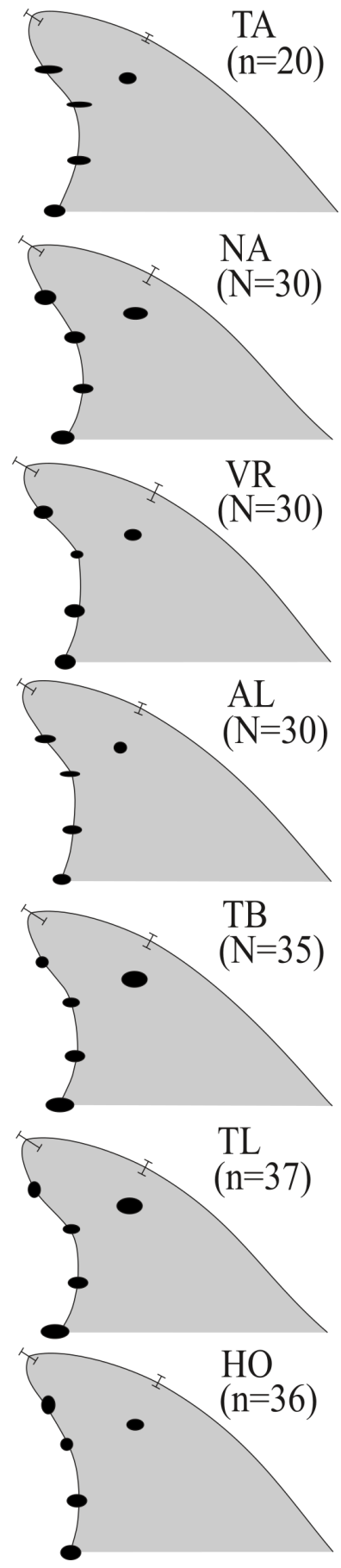

Figure 3 Median dorsal fin contours by study areas ( $N=\mathbf{5 3 3}$ dorsal fins). Regional divisions are grouped in columns: (A) Pacific Ocean, (B) Gulf of California and (C) Gulf of Mexico. Contours reflect median values of shape and do not represent any particular dorsal fin. Study area codes follow those in Fig. 1, and sample size is shown in parenthesis; error bars and ellipses show variability expressed as quartiles ( $50 \%$ of data). Measurement $\mathrm{AB}$ (i.e., from the tip to the anterior insertion into the body) is the same for all fins (10 relative units). 


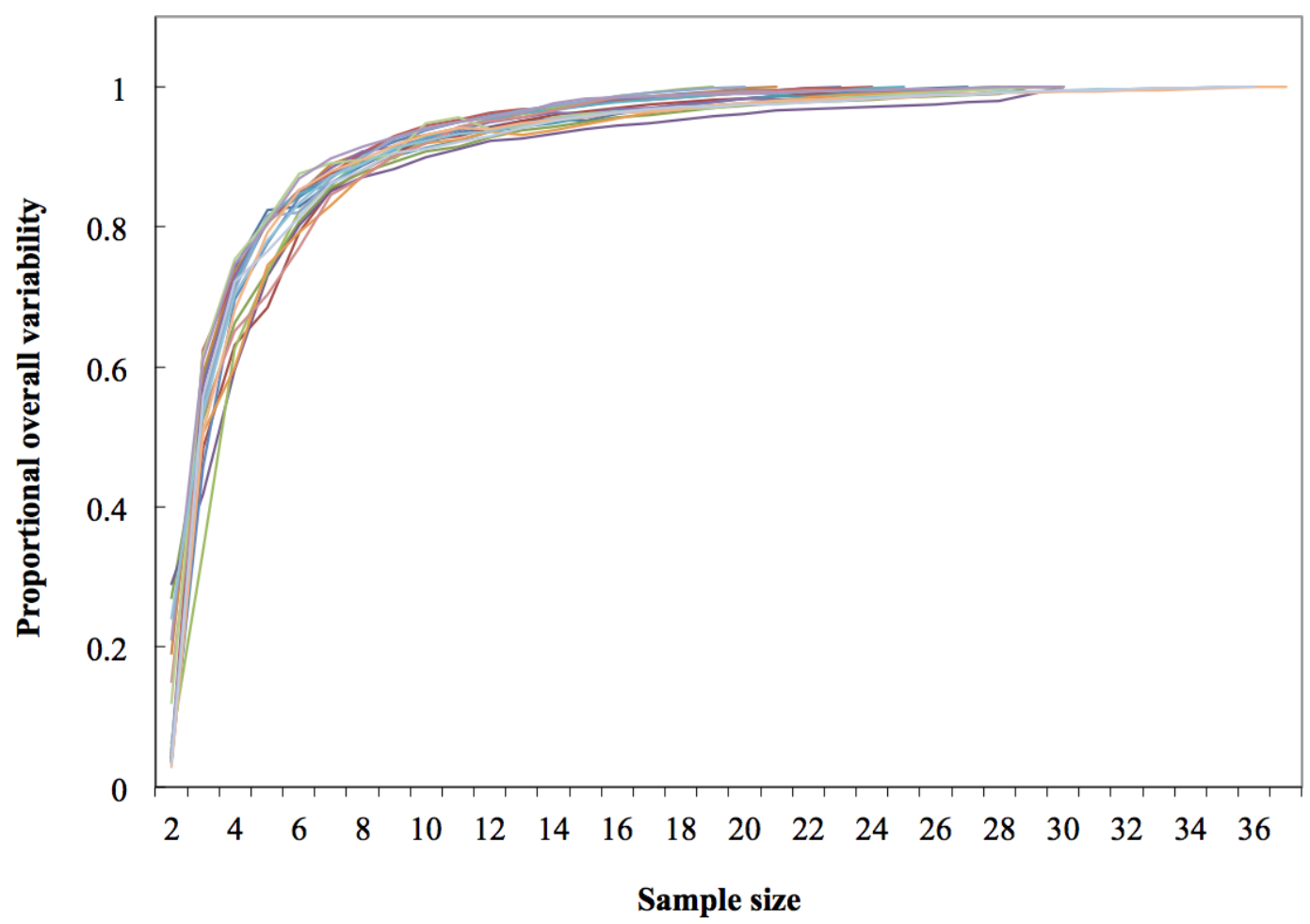

Figure 4 Dorsal fin morphological variability and sample size effect within the 19 study areas $(N=$ 533 dorsal fins).

Table 2 Factor Analysis of log-transformed ratios using all locations $(N=533)$. Note that the cumulative variance accounted for the first three Factors $\left(^{*}\right)$. Discrimination was highly significant among the 12 locations (Wilks' Lambda: $0.44442, F_{(33,922)}=8.8617, p<0.00001, N=533$ ).

\begin{tabular}{lllllll} 
Factor & Eigenvalue & $\begin{array}{l}\text { Cumulative } \\
\text { variance }(\%)\end{array}$ & $\begin{array}{l}\text { Wilks' } \\
\text { Lambda }\end{array}$ & $\begin{array}{l}\text { Partial } \\
\text { Lambda }\end{array}$ & $\begin{array}{l}\boldsymbol{F} \text {-remove } \\
(\mathbf{1 1}, \mathbf{3 1 3})\end{array}$ & $\boldsymbol{p}$-level \\
\hline 1 & 5.69 & 44.89 & 0.70 & 0.61 & 18.90 & $<0.001$ \\
\hline 2 & 2.98 & 72.79 & 0.52 & 0.81 & 6.76 & $<0.001$ \\
3 & 2.43 & $94.74^{\star}$ & 0.51 & 0.84 & 5.66 & $<0.001$ \\
\hline
\end{tabular}

Mazatlan and Tamiahua). The most distinctive samples were from $\mathrm{La} \mathrm{Paz}$ and Puerto Escondido (18 significant differences), followed by San Jorge, Bahia de los Angeles (16 each), and Santa Maria (15); all other locations were significantly different to 13 other sites.

Cluster analysis revealed two geographic groups, one corresponding to the localities from the Gulf of Mexico, including Santa Maria (Gulf of California) as a geographic outlier, and the second including localities from the Pacific and the Gulf of California exclusively (Fig. 5). Puerto Escondido was the most distinct locality and was not nested in any of the geographic groups.

A significant correlation was found between the Squared Mahalanobis and geographic distances (Mantel test, $r=0.35, p<0.001$ ); thus supporting the hypothesis of differentiation by distance and a stepping-stone dispersal model. Most of the contribution to the model came from samples within the Gulf of Mexico (partial Mantel test, $r=0.60$, 


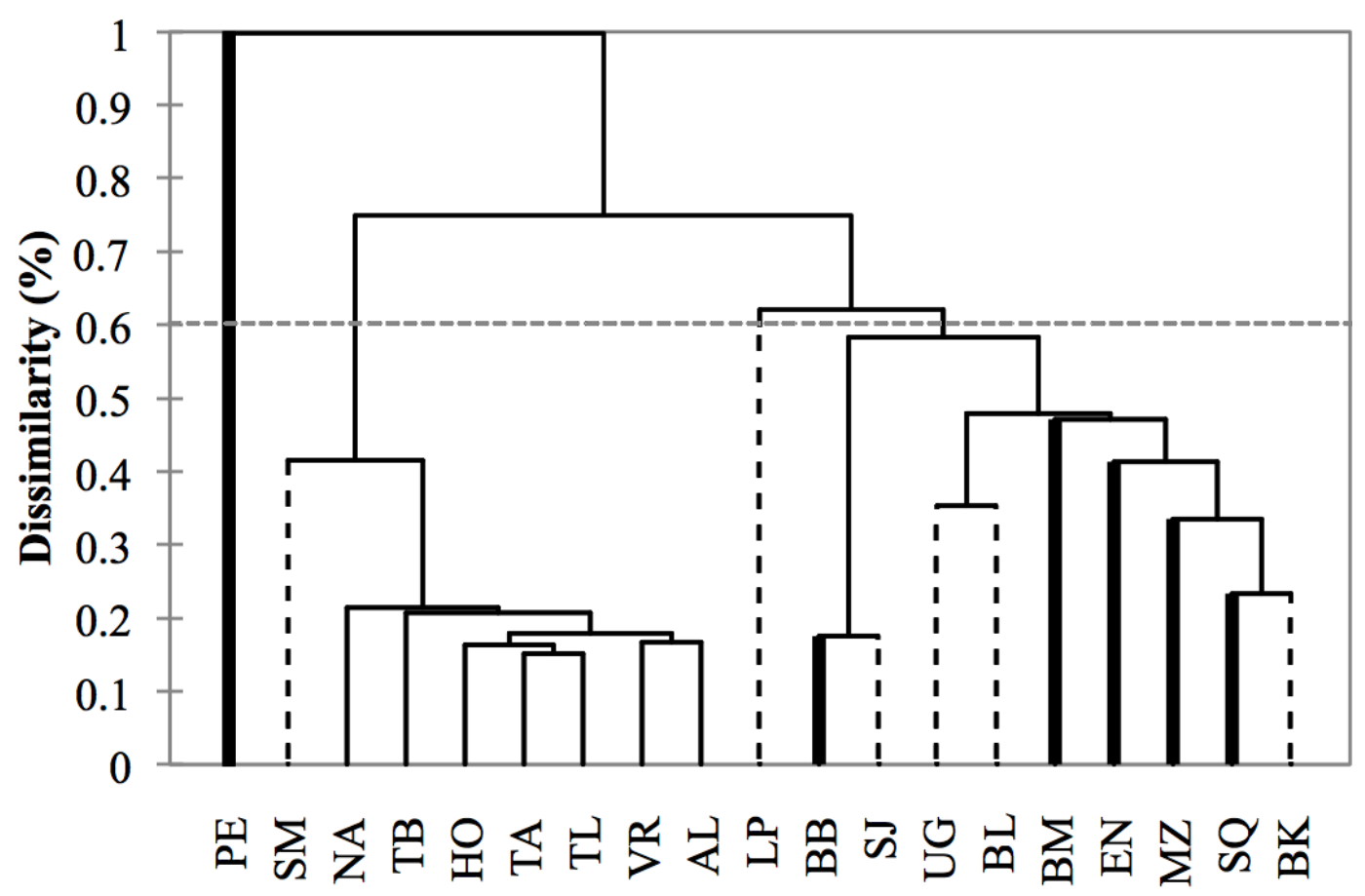

Figure 5 Dendrogram based on morphometric distances among study areas ( $N=\mathbf{5 3 3}$ dorsal fins). Study area codes follow those in Fig. 1. Values are proportions based on the maximum Squared Mahalanobis distance (Table 3). Major branches are somewhat consistent with the regional division of the study areas: (1) Pacific Ocean (bold lines), (2) Gulf of California (dashed lines), (3) Gulf of Mexico (thin lines).

$p<0.001$ ), followed by the Gulf of California (partial Mantel test, $r=0.50, p=0.054$ ) and the Pacific (partial Mantel test, $r=0.44, p=0.093$ ). This correlation broke down when samples from the Pacific and the Gulf of California were analyzed together (Mantel test, $r=0.20, p>0.11)$.

\section{DISCUSSION}

\section{Heredity and individual dispersal as mechanisms for phenotypic variability}

Morphological variations in dorsal fin characteristics of bottlenose dolphins inhabiting Mexican coastal waters were observed, even among study areas in near proximity (Figs. 1 and 5); this variation was evident in the averaged fin contour reconstructions (Fig. 3), which showed significant differences among most localities (Table 3, Fig. 5). Such statistical discrimination may be largely due to the low phenotypic variability within putative populations, such that a small number of individuals $(\sim 20)$ were needed to obtain at least $95 \%$ of the expected variability within any given locality (Fig. 4). Therefore, it is reasonable to assume that dorsal fin shape may be under strong selection acting over individuals with particular dorsal fin phenotypes. However, methodological and biological contexts must be considered in order to prevent misleading interpretations. For instance, the use of photographs may introduce some level of unaccounted bias in age/sex 


\begin{tabular}{|c|c|c|c|c|c|c|c|c|c|c|c|c|c|c|c|c|c|c|c|}
\hline $\begin{array}{l}\text { Study } \\
\text { area }\end{array}$ & EN & SQ & $\mathbf{B M}$ & MZ & BB & PE & UG & SJ & BL & BK & SM & LP & TA & NA & VR & $\mathrm{AL}$ & ТВ & $\mathrm{TL}$ & HO \\
\hline EN & 0 & 220 & 1352 & 4140 & 4540 & 5748 & 2870 & 3040 & 2520 & 3340 & 3730 & 1820 & - & - & - & - & - & - & - \\
\hline SQ & 0.51 & 0 & 1132 & 3920 & 4320 & 5528 & 2650 & 2820 & 2300 & 3120 & 3510 & 1600 & - & - & - & - & - & - & - \\
\hline $\mathrm{BM}$ & 0.59 & 0.47 & 0 & 2788 & 3188 & 4396 & 1607 & 1737 & 1257 & 2007 & 2677 & 557 & - & - & - & - & - & - & - \\
\hline MZ & 0.41 & 0.34 & 0.60 & 0 & 400 & 1608 & 1439 & 1269 & 1789 & 969 & 279 & 2489 & - & - & - & - & - & - & - \\
\hline BB & 2.22 & 0.59 & 0.58 & 0.62 & 0 & 1208 & 1720 & 1580 & 2020 & 1380 & 600 & 2720 & - & - & - & - & - & - & - \\
\hline PE & 3.80 & $4.01^{*}$ & 3.74 & $1.831^{*}$ & 2.28 & 0 & 3047 & 2877 & 3397 & 2577 & 1887 & 3978 & - & - & - & - & - & - & - \\
\hline UG & 0.55 & 0.48 & $1.413^{*}$ & 0.87 & $1.67^{*}$ & $4.21^{*}$ & 0 & 170 & 350 & 450 & 1110 & 1050 & - & - & - & - & - & - & - \\
\hline SJ & $3.10^{*}$ & $1.18^{*}$ & 0.944 & $1.17^{*}$ & 0.18 & $5.03^{*}$ & 2.69 & 0 & 480 & 300 & 980 & 1180 & - & - & - & - & - & - & - \\
\hline $\mathrm{BL}$ & $1.56^{*}$ & $1.30^{*}$ & $1.928^{*}$ & 0.96 & $2.40^{*}$ & $3.12^{*}$ & 0.35 & 3.55 & 0 & 750 & 1420 & 700 & - & - & - & - & - & - & - \\
\hline BK & $1.06^{*}$ & 0.23 & 0.481 & 0.91 & 0.73 & $3.73^{*}$ & 0.71 & 1.10 & 1.07 & 0 & 690 & 1450 & - & - & - & - & - & - & - \\
\hline SM & $4.60^{*}$ & $2.14^{*}$ & $1.817^{*}$ & $2.16^{*}$ & 0.75 & $4.68^{*}$ & 2.87 & 0.85 & 2.88 & 1.87 & 0 & 2120 & - & - & - & - & - & - & - \\
\hline LP & 0.620 & $1.00^{*}$ & 0.898 & $1.92^{*}$ & $2.16^{*}$ & $5.32^{*}$ & 1.14 & 3.40 & 2.72 & $2.19^{*}$ & 4.536 & 0 & - & - & - & - & - & - & - \\
\hline TA & $4.44^{*}$ & $2.24^{*}$ & $2.146^{*}$ & $1.71^{*}$ & $1.42^{*}$ & $1.57^{*}$ & $2.23^{*}$ & $1.77^{*}$ & $1.64^{*}$ & $1.66^{*}$ & 0.42 & $4.98^{*}$ & 0 & 137 & 284 & 348 & 695 & 786 & 1428 \\
\hline NA & $5.02^{*}$ & $4.65^{*}$ & $4.867^{*}$ & $3.19^{*}$ & $1.80^{*}$ & $1.31^{*}$ & $3.74^{*}$ & $2.18^{*}$ & $1.29^{*}$ & $2.18^{*}$ & $3.74^{*}$ & $2.68^{*}$ & 0.25 & 0 & 147 & 211 & 558 & 748 & 1326 \\
\hline VR & $4.34^{*}$ & $5.08^{*}$ & $5.321^{*}$ & $4.20^{*}$ & $2.12^{*}$ & $1.40^{*}$ & $2.91^{*}$ & $2.33^{*}$ & $1.19^{*}$ & $1.83^{*}$ & $4.19^{*}$ & $2.43^{*}$ & 0.34 & 0.29 & 0 & 64 & 411 & 601 & 1179 \\
\hline AL & $4.12^{*}$ & $3.77^{*}$ & $4.432^{*}$ & $4.07^{*}$ & $2.38^{*}$ & $1.32^{*}$ & $3.98^{*}$ & $2.48^{*}$ & $1.18^{*}$ & $1.39^{*}$ & $4.29^{*}$ & $2.60^{*}$ & 0.18 & 0.21 & 0.17 & 0 & 347 & 537 & 1115 \\
\hline TB & $4.29^{*}$ & $4.31^{*}$ & $4.876^{*}$ & $3.65^{*}$ & $2.46^{*}$ & $1.06^{*}$ & $3.65^{*}$ & 2.56 & $1.32^{*}$ & $1.41^{*}$ & $3.59^{*}$ & $2.83^{*}$ & 0.47 & 0.40 & 0.37 & 0.28 & 0 & 126 & 768 \\
\hline TL & $4.34^{*}$ & $2.47^{*}$ & $4.145^{*}$ & 2.86 & $2.04^{*}$ & $1.25^{*}$ & $1.89^{*}$ & $2.70 *$ & 1.17 & $1.98^{*}$ & 0.92 & $4.85^{*}$ & 0.15 & 0.52 & 0.35 & 0.47 & 0.21 & 0 & 642 \\
\hline $\mathrm{HO}$ & $6.14^{*}$ & $3.85^{*}$ & $3.143^{*}$ & $3.96^{*}$ & $3.07^{*}$ & 1.00 & $3.22^{*}$ & 3.75 & $2.12^{*}$ & $3.32^{*}$ & $1.24^{*}$ & $6.52^{*}$ & 0.40 & 0.86 & 0.74 & 0.63 & 0.36 & 0.16 & 0 \\
\hline
\end{tabular}

Notes.

${ }^{*}$ significant distances $(\alpha<0.01)$.

-Not applicable. 
representation in the sample (Hersh \& Duffield, 1990; Gao, Zhou \& Wang, 1995; Weller, 1998; Perrin \& Mesnick, 2003).

A similar line of reasoning can be applied to the regional clusters found in this study. For instance, the high migratory rates documented for bottlenose dolphins in the northern Mexican Pacific (Defran et al., 2015) may explain the inter-study area dorsal fin similarities (Fig. 3) and low dissimilarity values (Table 3) despite the large distances among sites (Figs. 1 and 5). Detailed body morphometrics provided by Walker (1981) already support phenotypic similarity of bottlenose dolphins along the west coast of Baja California.

Results from the Gulf of California stand in sharp contrast to those from the Pacific in that even when geographic separation among localities was relatively low, $73 \%$ of the comparisons within this region showed significant differences (Table 3, Fig. 5). There is currently no information on migration rates for dolphins among all of these areas; however, based on morphometric analyses of skulls from dead stranded bottlenose dolphins, Vidal (1993) suggested a geographic regionalization akin to the differentiation found in this study. This pattern has been reported in several other taxa including invertebrates (Correa \& Carvacho, 1992; De la Rosa et al., 2000), fish (Riginos \& Nachman, 2001), and other marine mammals like the California sea lion (Zalophus californianus californianus) (Schramm, 2002; Aurioles et al., 2004; Pedernera et al., 2004; Porras et al., 2004). Contrasting oceanographic patterns (Lavín, Palacios-Hernández \& Cabrera, 2003) may contribute to this separation, causing habitat and resource partitioning. Moreover, Segura et al. (2006) also found genetic structures in bottlenose dolphins within the Gulf of California, which supports our findings. Overall, molecular and phenotyoic co-variation (i.e., skull and dorsal fin morphometrics) point to the possibility of the early steps of microevolutionary divergence in T. truncatus from the Gulf of California.

Conversely, no significant morphological differences were found within the Gulf of Mexico, but fin shapes were significantly correlated with distance among locations (Table 3, Fig. 5). Similar to the highly migratory movements of dolphins along the Pacific coast, bottlenose dolphins in the Gulf of Mexico also appear to have large home ranges. For instance, Delgado (2002) documented one individual that moved at least $800 \mathrm{~km}$ from Holbox Island to the western coast of the Gulf in less than a year; he also found four other individuals that moved 240-320 km in 274-1,404 days. Martinez-Serrano et al. (2011) and Morteo, Rocha-Olivares \& Abarca-Arenas (2017) also found large home ranges (>100 km) and individual movements (100-300 km) for dolphins in the northwestern Gulf of Mexico. Since dolphins may potentially reproduce with individuals from other locations, genetic exchange occurs over a large scale (Islas, 2005); however, evidence also suggests a certain degree of genetic structure and restricted gene flow that is consistent with sex-specific dispersal patterns (Islas, 2005; Caballero et al., 2012), which may enhance homogeneity in character states by male dispersion, but also promote differentiation through female restricted home ranges (e.g., Morteo, Rocha-Olivares \& Abarca-Arenas, 2014), potentially resulting in the observed clinal morphological trends.

Male dispersal patterns seem to be a dominant feature in the western Gulf of Mexico (Morteo, Rocha-Olivares \& Abarca-Arenas, 2014), thus our morphological results seem concordant with genetic data; however, morphological similarities in this trait may be also 
be attributed to the homogeneity and stability of the environment (a possible mechanism is further discussed in 'Could dorsal fin phenotypic variability be an adaptive trait?'). For instance, compared to the Gulf of California, tides, wave regimes and SST variations in the Gulf of Mexico are much lower in magnitude and frequency due to the influence of the Loop Current (Davis et al., 1998); and because of its influence over a large area (Avise, 1992), selective pressures may be similar in spite of the larger distance among sites. This situation may explain not only the similarities in shape among neighboring locations, but also the smaller overall variability observed in these dorsal fins (Fig. 3).

\section{Dorsal fin phenotypic variability as a function of geographic/geologi- cal scales}

Similar studies have also pointed out the potential utility of using geographic variation in dorsal fin shape for bottlenose dolphin population discrimination over wide geographic ranges (i.e., Indian and Pacific oceans vs. the Gulf of Mexico), thus intrinsic differences are somewhat implied (Weller, 1998); however, due to the wide geographic scale of such comparisons, random fin phenotypes may occur due to vicariance. Therefore, there was no other study to provide further insight in the dorsal fin morphology of bottlenose dolphins by using a larger sample at a smaller scale.

Moreover, the major differences in dorsal fin shapes found between the Pacific, the Gulf of Mexico and the Gulf of California were consistent with the stepping-stone dispersal model (Table 3); however, there was no clear difference between the Pacific and the Gulf of California.

The geological history of the region may shed light on the matter; for instance, the divergence between the Gulf of Mexico and Pacific populations ensued after the emergence of the Isthmus of Panama, which closed the inter-oceanic canal (approx. 2.5 Mya) (Gore, 2003); therefore, morphological differences with the Gulf of Mexico may also be attributed to vicariance. Conversely, the Baja California peninsula began to separate from the mainland about 5.5 Mya; during this separation (5.5-1 Mya) the peninsula was fragmented on several occasions by trans-peninsular seaways, connecting the Pacific and the Gulf (Riddle et al., 2002). It is unclear how these hypothetical connections between the proto-Gulf of California and the Pacific may have affected coastal populations of bottlenose dolphins; however, this intermittent isolation may account for the lack of differentiation in dorsal fin shape between the Pacific (Ensenada and San Quintin) and the northern Gulf of California.

\section{Could dorsal fin phenotypic variability be an adaptive trait?}

Local phenotypic variability in dorsal fins may be the result of individual heredity and dispersal, but natural selection may also be at play. While empirical data on the possible functional advantages of dorsal fin characteristics are sparse, it has been argued that some features are adaptive (Fish \& Hui, 1991; Weller, 1998; Berta \& Sumich, 1999; Fish \& Rohr, 1999; Reynolds, Wells \& Eide, 2000). As a whole, dorsal fin shape may be a trade-off between thermoregulatory capacities and hydrodynamic performance. For instance, regardless of the study location, the central portion of the trailing edge (represented by points $\mathrm{C} 10$ and C20, Fig. 2) was the least variable section of the dorsal fin overall (Fig. 3). This finding may 
reflect a hydrodynamic constraint, since computer simulations for hypothetical dorsal fins have found that this region produces the least turbulence (Pavlov \& Rashad, 2012). On the other hand, studies on thermoregulation efficiency in dorsal fins point out the importance of surface area and vascularization in temperature regulation (Meagher et al., 2002; Morteo, 2004; Westgate et al., 2007; Barbieri et al., 2010). For instance, veins and vessels in the dorsal fins of male dolphins are directly connected to the testicles (which are inside the body), helping in heat dissipation (Rommel et al., 1994; Rommel, Pabst \& McLellan, 1999).

The functional significance of other morphometric characters (i.e., foil, rake, depth, base lenght) are less clear. Weller (1998) explained how the shape of surfboard fins and water craft keels confer different levels of maneuverability, speed and performance; he further suggested how variation in these parameters in the dorsal fins may relate to site specific hydrodynamic performance required for prey chase and capture by dolphins. For instance, contrasting fin shapes have been described for the two ecotypes of this species in the southeast Pacific which have different feeding habits, such that offshore individuals generally have wider and more falcate fins than their coastal counterparts (Felix et al., 2017).

Alternatively, dorsal fin shape characteristics may be influenced by habitat variables unrelated to prey capture. For instance, falcate and wider fins (which theoretically perform better at high speeds or in highly dynamic environments) were found mainly in the Pacific (Fig. 3), where the habitat of coastal bottlenose dolphins features swells as high as $5 \mathrm{~m}$ (Lizárraga et al., 2003), and also in the Gulf of California, where tidal currents may exceed $3 \mathrm{~m} \mathrm{~s}^{-1}$ (Álvarez, 2001). Comparatively, less falcate fins were found in the Gulf of Mexico, where tidal currents and wave heights are of lesser magnitude (Delgado, 2002).

Additionally, dorsal fins that were less falcate and with less foil were found in the western Gulf of Mexico, whereas taller and wider (i.e., larger depth and base length) dorsal fins were found in the northern Gulf of California; both of these features resulted in larger fin surface areas. These coastal locations are very shallow $(<20 \mathrm{~m})$ and have a high potential for rising sea surface temperatures (SST) due to high residency times resulting from reduced water circulation, especially during low tides (Bianchi, Pennock \& Twilley, 1999; Lavin $\&$ Marinone, 2003). SST plays an important role in species distributions (Pianka, 1994; Valiela, 1995), and although it is not supposed to influence dolphins movements overall (due to their high thermoregulatory capacities), tagged bottlenose dolphins in the Atlantic have shown avoidance of oceanic fronts (Wells et al., 1999). Consequently, rapid changes in temperature may trigger behavioral and physiological responses possibly influencing home ranges, and also food habits and consumption rates. Thus a possible cause for the apparent relationship with proportional dorsal fin area may be that warmer habitats are more suitable for individuals that are better at handling heat excess.

In light of the above, there is a chance that unexpected morphological similarities between geographically isolated localities (e.g., Santa Maria in the Gulf of California vs. Gulf of Mexico sites, Fig. 5) are not an artifact of the classification functions (Table 2), and may have a biological/adaptive explanation. For instance, unlike the other study areas in the Gulf of California, Bahia Santa Maria is an enclosed estuarine system with two entrances, and the vegetal coverage along the shore is dense (Reza, 2001). Also, mean year-round SSTs are more similar to those in the Gulf of Mexico than to the open Pacific coast 
(Heckel, 1992; Schramm, 1993; Delgado, 1996; Delgado, 2002). Therefore, we speculate that similar dorsal fin shapes in the Gulf of California and the Gulf of Mexico may reflect adaptive convergence influenced by similar selective pressures.

We acknowledge that the relations described above may be coincidental and the former arguments are exploratory. Therefore, independent evidence is needed to understand if these polymorphisms reflect adaptive advantages and genetic mechanisms within and among populations, or are just the result of different norms of reaction. Although the patterns of morphological variation are somewhat consistent with biological and ecological features, suggesting adaptive explanations for such differences, hydrodynamic and thermoregulatory functions must be empirically assessed to determine if the character states found in this study are different enough to influence individual fitness, and thus subject to selection.

\section{CONCLUSIONS}

Dorsal fins of bottlenose dolphins show a high degree of polymorphism and restricted local variability. Dorsal fin polymorphisms were geographically structured at different spatial scales, supporting the model of isolation/differentiation by distance overall. Genetic analyses may help elucidate if the population structure is consistent with the morphological clinal variation described here. Our findings also suggest that this trait may be influenced by natural selection, but this hypothesis remains to be tested.

\section{ACKNOWLEDGEMENTS}

This research was part of the M.Sc. thesis of the lead author. We acknowledge the curators and owners of the photo-identification catalogs, which were used and analyzed under their supervision and permission (federal permits for their field work can be consulted in each case): Lisa Ballance, Martha Caldwell, RH Defran, Alberto Delgado-Estrella, Raúl Díaz-Gamboa, Oscar Guzón, Gisela Heckel, Paloma Ladrón de Guevara, Irelia López, Eduardo Lugo, Adriana Orozco, Héctor Pérez-Cortés, Tania Ramírez, Maru Rodríguez, Ivett Reza, Mario Salinas, and Yolanda Schramm.

\section{ADDITIONAL INFORMATION AND DECLARATIONS}

\section{Funding}

This research was part of the M.Sc. thesis of the lead author who benefited from a CONACyT (Consejo Nacional de Ciencia y Tecnología) graduate fellowship. Financial aid was also provided by a SNI (Sistema Nacional de Investigadores) scholarship provided by Saúl Álvarez-Borrego, and a thesis grant issued by the Department of Marine Ecology at CICESE. Logistics for the Gulf of California surveys were partially funded by Sergio Flores at UABCS and Drew Talley at UC-Davis. There was no additional external funding received for this study. The funders had no role in study design, data collection and analysis, decision to publish, or preparation of the manuscript. 


\section{Grant Disclosures}

The following grant information was disclosed by the authors:

SNI (Sistema Nacional de Investigadores).

Department of Marine Ecology at CICESE.

Sergio Flores at UABCS.

Drew Talley at UC-Davis.

\section{Competing Interests}

The authors declare there are no competing interests.

\section{Author Contributions}

- Eduardo Morteo conceived and designed the experiments, performed the experiments, analyzed the data, contributed reagents/materials/analysis tools, wrote the paper, prepared figures and/or tables, reviewed drafts of the paper.

- Axayácatl Rocha-Olivares and David W. Weller conceived and designed the experiments, contributed reagents/materials/analysis tools, wrote the paper, reviewed drafts of the paper.

- Rodrigo Morteo performed the experiments, contributed reagents/materials/analysis tools, wrote the paper, reviewed drafts of the paper.

\section{Animal Ethics}

The following information was supplied relating to ethical approvals (i.e., approving body and any reference numbers):

Our methods involved only non-invasive data collection (i.e., images were taken onboard a boat that was $15-50 \mathrm{~m}$ away from the animals), thus a Review Board was unnecessary.

\section{Field Study Permissions}

The following information was supplied relating to field study approvals (i.e., approving body and any reference numbers):

Original photographs from wild dolphins were obtained through federal permit from Secretaría del Medio Ambiente y Recursos Naturales (SEMARNAT) issued to a former thesis committee member (Gisela Heckel), with approval number: SGPA/DGVS/518. The remaining images came from photo-identification catalogs from other published and unpublished scientific research; thus it was assumed that all these were approved by their Institutional Review Boards (whenever this applied) and were issued with the federal permits for their field work, such that these can be consulted in each case.

\section{Data Availability}

The following information was supplied regarding data availability:

The dataset is provided in a Supplementary File with a detailed summary of the statistical tests and graphs. The procedure for the reconstruction of average dorsal fin contours is detailed in Appendix A of a technical report, which was also provided as a Supplementary File. 


\section{Supplemental Information}

Supplemental information for this article can be found online at http://dx.doi.org/10.7717/ peerj.3415\#supplemental-information.

\section{REFERENCES}

Acevedo A. 1989. Uso del área por el tursión (Tursiops truncatus) en la Ensenada de La Paz, durante el verano de 1987. Undergraduate thesis, Universidad Autonoma de Baja California Sur, La Paz, Mexico, 115.

Aleyev YG. 1977. Nekton. Hague: W. Junk b.v. Publishers, 435.

Álvarez S. 2001. The Colorado River Estuary and Upper Gulf of California, Baja, Mexico. In: Seeliger U, Kjerfve B, eds. Ecological studies, vol. 44. Berlin, Heidelberg: SpringerVerlag, 331-340.

Aurioles D, Porras H, Aguíniga S, Salazar S. 2004. Diferencias de $\delta^{15} \mathrm{~N}$ y $\delta^{13} \mathrm{C}$ entre Zalophus spp. del Golfo de California e Islas Galápagos: Dime qué comes y te diré quién eres. In: Abstracts of the XXIX international meeting for the study of marine mammals. La Paz, Baja California, Mexico: Sociedad Mexicana de Mastozoología Marina, 19.

Avise JC. 1992. Molecular population structure and the biogeographic history of a regional fauna: a case history with lessons for conservation biology. Oikos 63:62-76 DOI $10.2307 / 3545516$.

Ballance LT. 1987. Ecology and behavior of the bottlenose dolphin, Turiops truncatus, in the Gulf of California, Mexico. MSc thesis, Department of Biology, San Jose State University, San Jose, CA, USA, 49.

Ballance LT, Leatherwood S, Reeves RR. 1990. Residence patterns, group organization, and surfacing associations of bottlenose dolphins in Kino Bay, Gulf of California, Mexico. In: The bottlenose dolphin. San Diego: Academic Press, 267-283.

Ballance LT. 1992. Habitat use patterns and ranges of bottlenose dolphin in the Gulf of California, Mexico. Marine Mammal Science 8:262-274

DOI 10.1111/j.1748-7692.1992.tb00408.x.

Barbieri MM, McLellan WA, Wells RS, Blum JE, Hofman S, Gannon J, Pabst DA. 2010. Using infrared thermography to assess seasonal trends in dorsal fin surface temperatures of free-swimming bottlenose dolphins (Tursiops truncatus) in Sarasota. Bay, Florida. Marine Mammal Science 26(1):53-66 DOI 10.1111/j.1748-7692.2009.00319.x.

Berta A, Sumich JL. 1999. Marine mammals: evolutionary biology. San Diego: Academic Press, 494.

Bianchi TS, Pennock JR, Twilley RR. 1999. Biogeochemestry of Gulf of Mexico estuaries. New York: John Wiley \& Sons, Inc., 428.

Caballero S, Islas-Villanueva V, Tezanos-Pinto G, Duchene S, Delgado-Estrella A, Sanchez-Okrucky R, Mignucci-Giannoni A. 2012. Phylogeography, genetic diversity and population structure of common bottlenose dolphins in the Wider Caribbean inferred from analyses of mitochondrial DNA control region sequences and 
microsatellite loci: conservation and management implications. Animal Conservation 15:95-112 DOI 10.1111/j.1469-1795.2011.00493.x.

Caldwell M. 1992. A comparison of bottlenose dolphins identified in San Quintin and the Southern California Bight. MSc thesis, San Diego State University, San Diego, CA, USA, 58.

Correa SF, Carvacho B. 1992. Efecto de la "barrera de las islas" en la distribución de los braquiuros (Crustacea: Decapoda) en el Golfo de California. Proceedings of the San Diego Society of Natual History 26:1-4.

Davis RW, Farigon GS, May N, Leming TD, Baumgartner M, Evans WE, Hansen LJ, Mullin K. 1998. Physical habitat of cetaceans along the continental slope in the north-central and western Gulf of Mexico. Marine Mammal Science 14:490-507 DOI 10.1111/j.1748-7692.1998.tb00738.x.

Defran RH, Caldwell M, Morteo E, Lang AR, Rice MG, Weller DW. 2015. Possible stock structure of coastal bottlenose dolphins off Baja California and California revealed by photo-identification research. Bulletin of the Southern California Academy of Sciences 14:1-11 DOI 10.3160/0038-3872-114.1.1.

Defran RH, Weller DW, Kelly DL, Espinosa MA. 1999. Range characteristics of Pacific coast bottlenose dolphins (Tursiops truncatus) in the Southern California Bight. Marine Mammal Science 15:381-393 DOI 10.1111/j.1748-7692.1999.tb00808.x.

De la Rosa J, Escobar R, Correa F, Maqueda M, De la Torre J. 2000. Genetic structure of two comercial penaeids (Panaeus californiensis and P. stylirostris) from the Gulf of California, as revealed by allozyme variation. Fishery Bulletin 98:674-683.

Delgado A. 1996. Ecología poblacional de las toninas, Tursiops truncatus, en la Laguna de Yalahau, Quintana Roo, México. MSc thesis, Facultad de Ciencias, Universidad Nacional Autonoma de Mexico, Mexico, DF, 160.

Delgado A. 2002. Comparación de parámetros poblacionales de las toninas, Tursiops truncatus, en la región sureste del Golfo de México (Estados de Tabasco, Campeche, Yucatán y Quintana Roo). Doctoral thesis, Facultad de Ciencias, Universidad Nacional Autonoma de Mexico, Mexico, DF, 160.

Díaz RE. 2001. Tamaño poblacional y residencia de las toninas (Tursiops truncatus) en la ensenada de La Paz, BCS 1998-1999. Undergraduate thesis, Facultad de Medicina Veterinaria y Zootecnia, Universidad Autónoma de Yucatán, Merida, Yucatan, Mexico, 77.

Espinosa MA. 1986. Biología poblacional del delfín costero Tursiops truncatus en la costa noroccidental de Baja California, México. Undergraduate thesis, Facultad de Ciencias Marinas, Universidad Autonoma de Baja California, Ensenada, Mexico, 54.

Felix F, Van Waerebeek K, Sanino GP, Castro C, Van Bressem MF, Santillán L. 2017. Morphological variation in dorsal fins among common bottlenose dolphin populations in the Southeas Pacific Ocean. Report to the International Whaling Commision SC/67A/SM/02, 1-10.

Fish FE. 1998. Comparative hydrodynamics of odontocete cetaceans: morphological and ecological correlates with swimming performance. Journal of Experimental Biology 201:2867-2877. 
Fish FE, Hui CA. 1991. Dolphin swimming—a review. Mammal Review 21:181-195 DOI 10.1111/j.1365-2907.1991.tb00292.x.

Fish FE, Rohr JJ. 1999. Review of dolphin hydrodynamics and swimming performance. Technical report. United States Navy-SPAWAR Systems Center, San Diego, CA, USA, 196.

Gao A, Zhou K, Wang Y. 1995. Geographical variation in morphology of bottlenose dolphins (Tursiops sp.) in Chinese waters. Aquatic Mammals 21:121-135.

Goodwin JA, Durham BD, Peddemors VM, Cockroft VG. 1996. Genetic variation in the bottlenose dolphin Tursiops truncatus along the KwaZulu/Natal coast, South Africa. South African Journal of Marine Science 17:225-232 DOI 10.2989/025776196784158400.

Gore R. 2003. El origen de los mamíferos. National Geographic España 12(4):2-37.

Gotthard K, Nylin S. 1995. Adaptive plasticity and plasticity as an adaptation: a selective review of plasticity in animal morphology and life history. Oikos 74:3-17 DOI 10.2307/3545669.

Grimm LG, Yarnold PR. 1995. Reading and understanding multivariate statistics. Washington, D.C.: American Psicologycal Association, 373.

Guzón O. 2002. Distribución y movimientos del tursión (Tursiops truncatus) en la Bahia de Todos Santos, Baja California, México (Cetacea: Delphinidae). Undergraduate thesis, Facultad de Ciencias Marinas, Universidad Autónoma de Baja California, Ensenada, Baja California, Mexico, 156.

Heckel G. 1992. Fotoidentificación de tursiones Tursiops truncatus (Montagu, 1821) en la Boca de Corazones de la Laguna de Tamiahua, Veracruz, México (Cetacea: Delphinidae). Undergraduate thesis, Facultad de Ciencias, Universidad Nacional Autónoma de México, Mexico, DF, 164.

Hersh SL, Duffield DA. 1990. Distinction between Northwest Atlantic offshore and coastal bottlenose dolphins based on hemoglobin profile and morphometry. In: Leatherwood S, Reeves R, eds. The bottlenose dolphin. San Diego: Academic Press, 129-139.

Hoelzel AR, Potter CW, Best PB. 1998. Genetic differentiation between parapatric 'nearshore' and 'offshore' populations of the bottlenose dolphin. Proceedings of the Royal Society of London. Series B: Biological Sciences 265:1177-1183 DOI 10.1098/rspb.1998.0416.

Islas V. 2005. Genética de poblaciones y filogeografía de toninas Tursiops truncatus en el sur del Golfo de México y el Caribe. Tesis de Maestría, Universidad Nacional Autónoma de México, DF, México, 90.

Kachigan SK. 1991. Multivariate statistical analysis: a conceptual introduction. 2nd edition. New York: Radius Press, 303.

Kimura M. 1953. "Stepping Stone” model of population. Annual Report. National Institute of Genetics 3:62-63.

Ladrón de Guevara P, Heckel G. 2004. Diversidad, distribución y abundancia relativa de cetáceos en el Canal de Ballenas y Bahía de los Ángeles, Baja California, durante 
2003. In: Abstracts of the XXIX international meeting for the study of marine mammals. La Paz, Baja California, Mexico: Sociedad Mexicana de Mastozoología Marina, 74.

Lang TG. 1966. Hydrodynamic analysis of dolphin fin profiles. Nature 209:1110-1111 DOI 10.1038/2091110a0.

Lang TG, Pryor K. 1966. Hydrodynamic performance of porpoises (Stenella attenuata). Science 152:531-533 DOI 10.1126/science.152.3721.531.

Lavín MF, Marinone SG. 2003. An overview of the physical oceanography of the Gulf of California: a tribute to the scientific work of Pedro Ripa. Pp. 173-204. In: Velasco Fuentes OU, Sheinbaum J, Ochoa K, eds. Nonlinear processes in geophysical fluid dynamics. The Netherlands: Kluwer Academic Publishers, 376.

Lavín MF, Palacios-Hernández E, Cabrera C. 2003. Sea surface temperature anomalies in the Gulf of California. Geofísica Internacional 42:363-375.

Lizárraga R, Chee A, Gil E, Mendoza T, Martínez A. 2003. Effect of El Niño on the subaerial beach Playas de Rosarito, B.C., Mexico. Geofísica Internacional 42:419-428.

López I. 1996. Ecología poblacional de las toninas Tursiops truncatus en la costa de Tabasco, México. Tesis Profesional, Universidad Nacional Autónoma de México, Facultad de Ciencias, México, 77.

López I. 2002. Interacción de las toninas Tursiops truncatus, con las actividad pesquera en las costas de Tabasco, México. Tesis Maestría en Ciencias, Facultad de Ciencias, México, D.F, Universidad Nacional Autónoma de México, 84.

Manly BFJ. 1994. Multivariate statistical methods: a primer. London: Chapman and Hall, 215.

Martínez-Serrano I, Serrano A, Heckel G, Schramm Y. 2011. Distribution and home range of bottlenose dolphins (Tursiops truncatus off Veracruz, Mexico). Ciencias Marinas 37(4A):379-392 DOI 10.7773/cm.v37i4A.1860.

Meagher RM, McLellan WA, Westgate AJ, Wells RS, Frierson D, Pabst DA. 2002. The relationship between heat flow and vasculature in the dorsal fin of wild bottlenose dolphins Tursiops truncatus. Journal of Experimental Biology 205:3475-3486.

Mellink-Bijtel E, Orozco-Meyer A. 2006. Abundance, distribution, and residence of bottlenose dolphins (Tursiops truncatus) in the Bahía San Jorge area, northern Gulf of California, México. Aquatic Mammals 32(2):133-139 DOI 10.1578/AM.32.2.2006.133.

Morteo E. 2002. Distribución y movimientos del tursión (Tursiops truncatus; Montagu, 1821) en las aguas adyacentes a San Quintin, Baja California, México (Cetacea: Dephinidae). Undergraduate thesis, Facultad de Ciencias Marinas, Universidad Autónoma de Baja California, Ensenada, Baja California, Mexico, 146.

Morteo E. 2003. Morfología y función de la aleta dorsal de los delfines (familia Delphinidae) y su relación con el ambiente: un enfoque adaptativo. Baja California, Mexico: Centro de Investigación Científica y de Educación Superior de Ensenada, 33.

Morteo E. 2004. Dorsal fin morphological differentiation in bottlenose dolphins (Tursiops truncatus) along Mexican coasts: an adaptive approach. Tesis de Maestría, Centro de Investigación Científica y de Educación Superior de Ensenada, 131. 
Morteo E, Heckel G, Defran RH, Schramm Y. 2004. Distribution, movements and group size of the bottlenose dolphin (Tursiops truncatus; Montagu, 1821) south of Bahia San Quintin, Baja California, Mexico. Ciencias Marinas 30:35-46.

Morteo E, Martínez-Serrano I, Hernández-Candelario I, Ruiz-Hernández IA, GuzmánVargas EC. 2015. Distribución, abundancia, residencia y comportamiento del tursión (Tursiops truncatus) en el Sistema Arrecifal Veracruzano. Págs. 209-228. In: Granados-Barba A, Ortiz-Lozano LD, Salas-Monreal DY, González-Gándara C, eds. Aportes al Conocimiento del Sistema Arrecifal Veracruzano: hacia el corredor arrecifal del suroeste del Golfo de México. Universidad Autónoma de Campeche, 366.

Morteo E, Morteo R, Rocha-Olivares A. 2005. Diferenciación morfológica de poblaciones de tursión (Tursiops truncatus) en costas mexicanas. Technical Report CICESE No. 27119, Biological Oceanography Series. 22. Ensenada, Baja California, Mexico.

Morteo E, Rocha-Olivares A, Abarca-Arenas LG. 2014. Sexual segregation in coastal bottlenose dolphins (Tursiops truncatus) in the south-western Gulf of Mexico. Aquatic Mammals 40(4):375-385 DOI 10.1578/AM.40.4.2014.375.

Morteo E, Rocha-Olivares A, Abarca-Arenas LG. 2017. Abundance, residency and potential hazards for coastal bottlenose dolphins (Tursiops truncatus) off a productive lagoon in the Gulf of Mexico. Aquatic Mammals 43(3):308-319 DOI 10.1578/AM.43.3.2017.308.

Morteo E, Rocha-Olivares A, Arceo-Briseño P, Abarca-Arenas LG. 2012. Spatial analyses of bottlenose dolphin-fisheries interactions reveal human avoidance off a productive lagoon in the western Gulf of Mexico. Journal of the Marine Biological Association of the United Kingdom 92(8):1893-1900 DOI 10.1017/S0025315411000488.

Orozco A. 2001. Uso de hábitat por la tonina (Tursiops truncatus) y su relación con las mareas en la Bahia San Jorge, Sonora. MSc thesis, Departamento de Ecología Marina, CICESE Ensenada, Baja California, Mexico, 62.

Pauly ML, Palomares D. 1989. A multiple regression model for predicting the food consumption of marine fish populations. Australian Journal of Marine and Freshwater Research 40:259-273 DOI 10.1071/MF9890259.

Pavlov VV, Rashad AM. 2012. A non-invasive dolphin telemetry tag: computer design and numerical flow simulation. Marine Mammal Science 28:E16-E27 DOI 10.1111/j.1748-7692.2011.00476.x.

Pedernera C, Aurioles D, Torres J, Martínez O, Brousset DM, Parás A. 2004. Análisis geográfico de incidencia de Leptospira interrogans sensu lato en crías de lobo marino Zalophus californianus en el Golfo de California. In: Abstracts of the XXIX international meeting for the study of marine mammals. La Paz, Baja California: Sociedad Mexicana de Mastozoología Marina, 24.

Peres-Neto PR, Jackson DA. 2001. How well do multivariate data sets match? The advantages of a Procrustean superimposition approach over the Mantel test. Oecologia 129(2):169-178 DOI 10.1007/s004420100720.

Pérez-Cortes H. 2006. Comparación de las poblaciones de toninas, Tursiops truncatus, en Navachiste, Sin., y Bahía Magdalena, B.C.S., con fines de manejo. Doctorado en 
Ciencias Marinas Thesis, Instituto Politécnico Nacional, Centro Interdisciplinario de Ciencias Marinas, La Paz, B.C.S. México, 127.

Perrin WF, Mesnick SL. 2003. Sexual ecology of the spinner dolphin, Stenella longirostris: geographic variation in mating system. Marine Mammal Science 19:462-483 DOI 10.1111/j.1748-7692.2003.tb01315.x.

Pianka ER. 1994. Evolutionary ecology. 5th edition. New York: Harper-Collins College Publishers, 486.

Porras H, Aurioles D, Aguíniga S, García F. 2004. Variación alimentaria del lobo marino de California (Zalophus californianus) en el Golfo de California, México. In: Abstracts of the XXIX international meeting for the study of marine mammals. La Paz, Baja California: Sociedad Mexicana de Mastozoología Marina, 18.

Ramírez T, Morteo E, Portilla-Ochoa E. 2005. Basic aspects on the biology of the bottlenose dolphin, Tursiops truncatus, in the coast of Nautla, Veracruz, Mexico. Page 230. In: 16th Biennial conference on the biology of marine mammals. San Diego: The Society for Marine Mammalogy.

Reynolds JE, Wells RS, Eide SD. 2000. The bottlenose dolphin biology and conservation. Gainesville: University Press of Florida, 288.

Reza NI. 2001. Distribución y abundancia de Tursiops truncatus en la Bahia Santa María, Sinaloa, México. Undergraduate thesis, Facultad de Ciencias, Universidad Nacional Autonoma de México, Mexico, DF, 59.

Rice WR. 1989. Analyzing tables of statistical tests. Evolution 43:223-225 DOI 10.2307/2409177.

Riddle BR, Hafner DJ, Alexander LF, Jaeger JR. 2002. Cryptic vicariance in the historical assembly of a Baja California peninsular desert biota. Evolution 97:14438-14443.

Riginos C, Nachman MW. 2001. Population subdivision in marine environments: the contributions of biogeography, geographical distance, and discontinuous habitat to genetic differentiation in a blennioid fish, Axoclinus nigricaudus. Molecular Ecology 10:1439-1453 DOI 10.1046/j.1365-294X.2001.01294.x.

Rodríguez MA, Lugo E, Foubert Z. 2003. Ecology, behaviour and social structure of a resident group of bottlenose dolphin (Tursiops truncatus) in Banderas Bay. In: Abstracts of the XVIII international meeting for the study of marine mammals. Bahia Banderas, Nayarit: Sociedad Mexicana de Mastozoología Marina, 7.

Rodríguez-Vázquez MA. 2008. Abundancia y distribución espacio-temporal del tursión (Tursiops truncatus) en el norte de la Bahía de Banderas, Jalisco-Nayarit, México. Tesis de Maestría, Centro de Investigación Científica y de Educación Superior de Ensenada, 131.

Rommel S, Pabst A, McLellan W. 1999. Heat conservation and its vascular circumvention at the testes-convergence in dolphins, seals and manatees. In: Proceedings of the 13th Biennial conference on marine mammal biology. Wailea, Hawaii, USA: The Society for Marine Mammalogy, 162.

Rommel SA, Pabst DA, McLellan WA, Williams TM, Friedl WA. 1994. Temperature regulation of testes of the bottlenose dolphin (Tursiops truncatus): evidence form 
colonic temperatures. Journal of Comparative Physiology. B, Biochemical, Systemic, and Environmental Physiology 164:130-134 DOI 10.1007/BF00301654.

Ruíz-Hernández IA. 2014. Desplazamientos de toninas (Tursiops truncatus) en la costa central de Veracruz, México. Tesis de Licenciatura, Facultad de Biología, Universidad Veracruzana, Xalapa, Ver., México, 58.

Salinas MA, Bourillón LF. 1988. Taxonomía, diversidad y distribución de los cetáceos de la Bahia de Banderas, México. Undergraduate thesis, Universidad Nacional Autonoma de México, Mexico, DF, 211.

Schramm Y. 1993. Distribución, movimientos, abundancia e identificación del delfín Tursiops truncatus (Montagu, 1821), en el sur de la Laguna de Tamiahua, Ver. y aguas adyacentes (Cetacea: Delphinidae). Undergraduate thesis, Escuela de Biología, Universidad Autónoma de Guadalajara, Guadalajara, Jalisco, Mexico, 174.

Schramm Y. 2002. Estructura genética y filogeográfica del lobo marino de California (Zalophus californianus californianus) en aguas adyacentes a la península de Baja California, México. Doctorate thesis, Facultad de Ciencias Marinas, Universidad Autónoma de Baja California, Ensenada, Baja California, Mexico, 146.

Segura I, Rocha-Olivares A, Flores-Ramirez S, Rojas-Bracho L. 2006. Conservation implications of the genetic and ecological distinction of Tursiops truncatus ecotypes in the Gulf of California. Biological Conservation 133:336-346 DOI 10.1016/j.biocon.2006.06.017.

Silber G, Fertl D. 1995. Intentional beaching by bottlenose dolphins (Tursiops truncatus) in the Colorado river delta, Mexico. Aquatic Mammals 21:183-186.

Silber GK, Newcomer MW, Silber PC, Pérez-Cortés MH, Ellis GM. 1994. Cetaceans of the northern Gulf of California: distribution, occurrence, and relative abundance. Marine Mammal Science 10:283-298 DOI 10.1111/j.1748-7692.1994.tb00483.x.

Stearns SC. 1989. The evolutionary significance of phenotypic plasticity. BioScience 39:436-445 DOI 10.2307/1311135.

Turner JP, Worthy GAJ. 2003. Skull morphometry of bottlenose dolphins (Tursiops truncatus) from the Gulf of Mexico. Journal of Mammalogy 84:665-672.

Valiela I. 1995. Marine ecological processes. 2nd edition. New York: Springer-Verlag, 686.

Van der Hoop JM, Fahlman A, Hurst T, Rocho-Levine J, Shorter KA, Petrov V, Moore MJ. 2014. Bottlenose dolphins modify behavior to reduce metabolic effect of tag attachment. Journal of Experimental Biology 217:4229-4236 DOI 10.1242/jeb.108225.

Vidal LE. 1993. Variación geográfica de las dimensiones craneanas en toninas (Tursiops truncatus) del Mar de Cortés, México. Undergraduate thesis, Facultad de Ciencias, Universidad Nacional Autonoma de México, Mexico, DF, 42.

Walker WA. 1981. Geographical variation in morphology and biology of bottlenose dolphins (Tursiops) in the eastern North Pacific. Administrative Report Southwest Fisheries Center LJ/103C, La Jolla CA, USA, 20.

Weller DW. 1998. Global and regional variation in the biology and behavior of bottlenose dolphins. PhD thesis, University of Texas A\&M, TX, USA, 142. 
Wells RS, Rhinehart JL, Cunninham P, Whaley J, Baran M, Koberna C, Costa DP. 1999. Long distance offshore movements of bottlenose dolphins. Marine Mammal Science 15:1098-1114 DOI 10.1111/j.1748-7692.1999.tb00879.x.

Westgate AJ, McLellan WA, Wells RS, Scott MD, Meagher EM, Pabst DA. 2007.

A new device to remotely measure heat flux and skin temperature from free-

swimming dolphins. Journal of Experimental Marine Biology and Ecology 346:45-59

DOI 10.1016/j.jembe.2007.02.014.

Wright B. 2000. Form and function in aquatic flapping propulsion: morphology, kinematics, hydrodynamics, and performance of the triggerfishes (Tetraodontiformes: Balistidae). PhD thesis, University of Chicago, Chicago, IL, USA, 303.

Wright S. 1943. Isolation by distance. Genetics 28:114-138.

Zar JH. 1996. Biostatistical analysis. New Jersey: Prentice May, Upper Saddle River, 718. 